\title{
Surveying Elderly Respondents Regarding Electric Scooter Use
}

\author{
Wen-Chin Lee ${ }^{1}$,Cheng-Hung Huang ${ }^{2}$,Chih-Fu Wu ${ }^{3}$,Yi-Jung Lee ${ }^{4}$ \\ Program of Design Science, Tatung University, Taiwan, Tel. +886-923-235909, \\ Email: t067067@hotmail.com \\ ${ }^{2}$ Department of Media Design, Tatung University, Taiwan, Tel. +886-955-910761 \\ Email: chhuang@ttu.edu.tw \\ ${ }^{3}$ Department of Industrial Design, Tatung University, Taiwan, Tel. +886-968-357658 \\ Email: wcf@ttu.edu.tw \\ ${ }^{4}$ American apple company, Tel. +886923815968, Email: yijung.carol@gmail.com
}

\begin{abstract}
The rapid growth rate of the elderly population is a serious current issue in most countries, affecting them economically through needed medical treatment and healthcare planning. The priority concern is how to reduce the number of elderly people requiring long-term healthcare and raise the number who are able to live independently. This study executed a behavior assessment of elderly person's self-reported use of electric scooters and analyzed their degree of acceptance of these assisted living tools, partly through a related factor analysis of our survey instrument. We used this questionnaire survey as our research method, applying SPSS22 software for factor analysis that revealed five survey facets.
\end{abstract}

Key words: long-term care, elderly people, behavior assessment, factor analysis, independence

\section{Introduction}

1.1 Research Background

As the new generation of elderly people has strong spending power and a relatively high educational level, they are highly receptive to various information technologies in order to respond to potential business opportunities and meet their own needs. In this context, this study used a survey questionnaire to explore elderly people's attitudes and use of electric scooters and examine the difficulties they encounter and the future demand for these tools, given their driving habits, cognition, interaction with and operation of these instruments, and their general activities. Through these data, we hope to better understand and manage elderly people's electric mobility car needs in manner that is safe, healthy, and comfortable, with an end goal of enhancing quality of life among elderly people. 1.2 Research Motivation At present, estimates of the proportion of the elderly population (those over 65 years of age) in Taiwan from the National Development and Reform Commission (2016) suggest a rapid rise from 7\% in 1993 to $14 \%$ in 2018, with a projected estimate in 2026 of $20 \%$. In 2061, four out of every 10 people (40\%) are expected to be elderly, with all of these over 85 years of age. Characteristics of Taiwan's 
"aging" society are similar to those of other economically developed countries such as Europe, the United States and Japan; Taiwan's aging population possesses considerable wealth and spending power, and are their activity in business and social activities creates added business opportunities. Business enterprises have put forward appropriate goods and increased access to services to meet the needs of the elderly. Among these products, the electric mobility scooter is designed to solve the important problem of substantially increasing mobility among elderly people, making it likely to be very popular.

1.3 Research Purposes

With the advent of an aging society, the demand for medical aids of this kind is becoming increasingly urgent. In order to design a product that best suits their needs, this study explores elderly people's acceptance of this product and assesses factors related to its impact for enhancing their life functioning. The tool for this research is a fill-in-the-blank survey questionnaire. Participant respondents are elderly persons and their families who have been using electric scooters in an effort to avoid wasted time and costs in efforts to improve the future design and development of these devices.

\section{Literature Survey and Critique}

2.1 The Definition of the Elderly In the Civil Servant Insurance Law, the age of 65 is defined as the number of years due to be ordered to retire, while the provisions of the Labor Insurance Ordinance stipulating that those over the age of 55 may apply for the payment of the elderly. However, in general, demographic indicators used in determining the degree of social aging are as follows: elderly population index, aging index, dependent population index, etc., are calculated at the age of 65 . Elderly people in the face of changes in lifestyle, such as retirement, making the problems facing the whole life followed, excepting for some of the physiological decline caused by aging, facing the old age and death, widowed, narrow life circles, our scholars have many different opinions on the issue of the elderly in different viewpoints (Peng, 2000). The elderly have great heterogeneity in physiology, cognition and social structure relationship, and their developmental stages with their own characteristics. Therefore, it is necessary to address the heterogeneity of the elderly, especially it will understand the needs of the elderly and the types of needs for a correct estimation, we must understand the social and cultural characteristics of the elderly, the aging process is accompanied by a variety of functions, resulting in dysfunction of daily life activities, the elderly's food, clothing, shelter and transportation different from other age groups (Hus, 1991).

2.2 The impact and security of electric scooters on the elderly

Electric mobility scooters are medical-use petrol-powered or battery-powered medical devices for people with poor mobility as outdoor vehicles with a maximum speed limit of $10 \mathrm{~km} / \mathrm{h}$ (Ministry of Health and Welfare Medical Device Materials Library, 2015). Medical electric mobility scooters are classified as rehabilitation aids. Their main functions are to increase, improve or maintain the functions of daily life of the elderly and the physically and mentally handicapped, and safeguard the safety of going out.

The integration of resources for mobility aids such as $R \& D$, production, subsidies and services in the country has become an issue that the government attaches importance to in recent years. The mobility aids can help to enhance the ability to move independently. With the goal of self-awareness and self-esteem, and being able to move freely to any study or work, leisure and other places is very important. If you want to 
enhance the functional life of the silver hair, mobile aids are the necessary choices (Sargent, CA 2002).

2.3 The R\&D of electric scooter

The earliest electric wheelchair design was patented by Smith in 1940 but was not commonly used until 1957. Between 1976 and 1998, the scholars, C. A. MacLaurin, C. E. Brubaker, B. W. Johnson and Chung, Kao-Chi and so on in the Rehabilitation Engineering Center in the University of Virginia and the University of Pittsburg were engaged in R\&D of hand wheelchairs, electric wheelchairs and electric scooters, including ergonomics, structural/structural analysis and design and testing, clinical evaluation, wheelchair seat and support systems, dynamic and static test research reports, to provide the future electric wheelchairs and scooters integrated design, simulation analysis, and the choice of configuration as very important references. (Thacker. J. G. et al. 1994; MacLaurin. C. A. et al. 1981)

At present, the pipelines obtained in the domestic Taiwan for aids equipment mostly are sold in the hospital ward and are purchased in the largest amount of medical equipment, which shows that the public lack of awareness of aids equipment and at the same time will be more likely to receive from the hospital or medical equipment companies for easy trial or purchase of aids equipment, (Huang, et al. 2003). In many countries, the use of electric bicycles has been clearly defined. For the sake of driving safety, the electric bicycle with multiple restrictions is too fast $(25 \mathrm{~km} / \mathrm{h} \sim 30 \mathrm{~km} / \mathrm{h})$ to stop the output of auxiliary power. In addition to the inspection and verification of electric scooter aids, it also needs to enhance the road usage guidelines for the users of the scooters in Taiwan (Lin et al., 2009).

The most important function of the electric scooter is the transportation tools accepted by the silver-clad and mild-moderate-physical disabilities. The most important function of the electric scooter is to reduce the walking time and the burden on the two feet to support the body weight. The electric scooter must be installed in the park squares, supermarkets, amusement parks and other non-road use, to avoid traffic accidents.

2.4 The current status of electric scooter industry

Taiwan's main export medical equipment products to electric wheelchairs, electric scooters based in Taiwan is the fastest growing electric vehicle industry products. At present, China's export of medical products continues to grow from NT \$29 billion in 2007 to NT \$ 41.2 billion in 2011, with a CAGR of 9.2\% from 2007 to 2011 . The United States and Japan are the two largest exporters of medical device products in Taiwan, accounting for $42 \%$ of the total export value. They are two major markets to support the development of Taiwan's industry over the years. Their exports have maintained steady growth and their exports to other top five countries have also been fairly stable. Taking 2011 as an example, the major exporters of medical equipment in Taiwan are the United States, Japan, Mainland China, Germany and the United Kingdom. The total export value of the top five exporters has accounted for over $60 \%$ of the total export value, indicating that the export market is quite concentrated (Chang, 2013).

1. The current status of foreign development

The exports of electric locomotives from 2009 to 2014 (as of $30^{\text {th }}$, Sep., the Statistics of Customs Administration, MOF) are 19,556 cars totally. For the first nine countries, exports accounted for more than $80 \%$ of the exported motor vehicles, accounting for $20.2 \%$ of the Netherlands, France (16.9\%), Japan (10.6\%), the United States (7.3\%) and Australia (6.5\%), the United Kingdom (6.2\%), Germany (4.9\%), Belgium (4.2\%), and Denmark (3.7\%), respectively. European countries shares about 
$70 \%$ of Taiwan's exports of electric vehicles (66.7\%) (The Industrial Bureau, the Ministry of Economic Affairs, 2014).

2. The current status of Taiwan's development

The development of electric vehicles in Taiwan is dominated by electric locomotives. The domestic sales of electric locomotives have gradually grown from 27 in 2009, 3,061 in 2010, 7,563 in 2011, 8,066 in 2012,6,767 in 2013, and 4,404 units in 2014 ( $2^{\text {nd }}$ Sept. released of subsidy points until $19^{\text {th }}$, Dec.), with the cumulative sales of 29,888 units (The Industrial Bureau, Ministry of Economic Affairs, 2014).

Taiwan has a successful bicycle and locomotive industry with the advantages of developing light electric vehicles. Meanwhile, its systems of components and parts industries are well developed with the capable of rapid development and production. The development of key components for electric vehicles such as motors, controllers, battery monitors, power modules and others of many years of development has been reached at the internationally competitive forces. However, the battery charging or exchange system has not yet been established, the testing norms and regulations are not perfect, and the surrounding supporting measures are inadequate. The lithium battery powder material has been developed and has not yet been mass-produced yet and the above improvements still need to be improved.

\section{Research Methods and Procedures}

3.1 Method of questionnaire survey

The questionnaire survey is a method used by the researchers to collect data and is often used as a measure of personal behavior and attitude. The tools it uses are called questionnaires, and its usefulness lies in measurement, especially in the measuring of certain research variables structure. The questionnaire survey can sort out most people's ideas to organize them with statistical techniques, and related analytical techniques to achieve the understanding of the nature of the problem or where the key elements of the problem is a quantitative approach to the study (Kuan, et al., 2012).

1. Collect relevant information

(1) To collect information on the safety of elderly persons who use electric mobility scooters.

(2) Select senior veterans and their dependents using electric scooter for the elderly as the research object of the questionnaire survey.

2. This study is based on the self-designed "the Questionnaire on the Safety of Electric Scooters for Elderly People" as follows:

(1) To accept the basic information of the person who filled in: This part is to survey the distinction of gender, age and education of the person who accepted the questionnaire.

(2) Survey on the Safety Design Status for the Elderly Using the Electric Scooter:

A. How is the driving behavior of elderly people?

B. How is self-cognitive behavior of elderly people?

C. How is the interaction with the family?

D. How is the operating behavior of elderly people?

E. How is the driving environment activities behavior of elderly people?

3. This study is considered the capability of elderly people to answer: the use of Likert's scale method of filling in 5-points scale method, scale options are very often, often, sometimes, occasionally seldom, and almost never, The level of options circle to 5, 4, 3,2 , and 1 . 
4.The number of pre-test sample: After completing the pre-test questionnaire preparation, the implementation of the pre-test action, and the nature of the object in the future formal questionnaire are exactly the same.

3.2 Investigation process

The method of this questionnaire survey adopts the implementation of direct survey questionnaire, after the completion using statistical analysis.

1. Fill out the gender, age of the distinction as the basic information, selecting the elderly veteran and their dependents, the use of electric scooters for the elderly and there is experience driving electric scooter as the research object of the questionnaire.

2. Recycle the questionnaire.

3.3 Research principles

The study is based on the survey method. The survey method is applicable in the various fields, from sociology, psychology, business, etc., to understand the general public opinion, is required to adopt this method. In the design field, the quantification research has also adopted this method, and even popular perceptual engineering in the recent years, but also the use of survey methods to make the investigation method has become an important research method (Kuan et al., 2012). As for the method of statistical analysis, it is processed using the Social Science Statistics Package Software Program (SPSS 22).

The rationale for the survey is to give a response (or answer) to a representative group of respondents using a set of standard stimuli (eg, questionnaires) to estimate the overall population's attitude or behavior response to a particular problem. In addition to using this method in academic research, there more widely used in opinion polls, consumer opinion collection, marketing research and other applications. The largest advantage of the survey method is that it can collect the most and rigorous quantitative data in the shortest amount of time (Chiou, 2011).

The research and design in the field of social sciences, sociologists prefer to use investigation research or related research, psychologists focus on experimental design, thus regardless of experimental design or survey/related research, data/data analysis, all of them based on the computer, according to the variable attributes for the choice of appropriate statistical methods to test hypotheses, data collection methods commonly used include visits, surveys, observations, etc. (Wu, 2002).

The most important task of investigation and research is to deduce the characteristics of the population through samples. Therefore, the choice of samples becomes an important task of investigation. To ensure the accuracy of inference, the sample of investigation must be randomized, representative and sufficient sizes (Chiou, 2011), the nature of its analogize population will be more correct. Thus, how to choose the correctness of the sample for the population is determined by the following factors: whether the sample size is sufficient, and whether the sample selection method is appropriate, whether the information obtained from the samples is correct or not, the representativeness is the basic principle of sampling and also the indicator to judge whether the subjects are appropriate or not.

\section{Research Results}

\subsection{Data collection and collation analysis}

This Questionnaire investigation used a direct questionnaire survey, after the completion of the implementation of the statistical analysis of recovery methods, and selected from the elderly veterans and their dependents as the test object to conduct a questionnaire survey. As of September 1, 2016, 100 copies of the pretest questionnaire were sent out on September 1, 2016. After the questionnaires were sorted out, 5 copies 
of the questionnaires were rejected and 95 valid questionnaires were returned with the estimation at $95 \%$ confidence level. After finishing collection of the questionnaire, valid questionnaires will be input into the computer to log in and organize the project analysis using the Social Science Statistical Package Software Program (SPSS).

The project analysis calculates the "CRV" (Critical Ratio Value, i.e. CR value) of each item and ranks all the subjects in the pretest questionnaire based on their total sums. The top $25 \% \sim 33 \%$ of the scores are in the high score group, the bottom $25 \% \sim 33 \%$ of the scores are in the low score group, and the significant test (the highest $27 \%$ of the total score and the lowest $27 \%$ of the total scores in the test as the limits) to verify the differences between both of each item in average score in the significant level $(\alpha<0.05$ or $\alpha<0.01$ ), indicating that this item can identify the level of response of different items as a basis for whether the deletion.

4.2 The status of investigation and distribution

The survey statistics using the project analysis reliability test results excepts for the items of $10,15,18,20$, and 29 with the other 25 questions with the significant and discriminatory levels and the capacity questionnaire of this study initially proposed to include five factors, 25 questions, and in Likert's five points scoring way for the project points. In the aspect of construct validity, the pre-test scale has 25 questions left after the deletion of the item by project analysis. That is to say, the factor analysis program uses the package statistical software SPSS 22 to analyze the factors so as to extract the major factors and further analysis. Retest part of the questionnaire on October 1, 2016 issued a total of 320 copies, as of November 30, 2016, after the questionnaire recovery check, excluding the bad answer 16, and 304 valid questionnaires on the estimated at $95 \%$ confidence level.

4.3 The factor analysis of the elderly use in electric scooter behavior analysis

In the study, the first test of the project analysis reliability test results except to the items of 10, 15, 18, 20 and 29 and the remaining of 25 questions with the significant and discrimination levels. The test questions are corrected to 25 questions using of $\mathrm{KMO}$ and Bartlett's tests to 21 variables whether are suitable for the factor analysis? When the KMO value is less than 0.5 , it is less suitable for factor analysis. In the study, the KMO's value from the study was 0.682 , which indicating that suitable for factor analysis, in addition to Bartlett's test with $\chi^{2}$ value of $5039.684(\mathrm{~d} . \mathrm{f}=171)$ is in the significant level, representing the common factors exist between the relevant matrix of the populations, suitable for factor analysis, see table 1.

\begin{tabular}{|l|l|}
\hline \multicolumn{2}{|c|}{ Table 1: KMO and Bartlett's Test Table } \\
\hline $\begin{array}{l}\text { Kaiser-Meyer-Olkin measure of sampling } \\
\text { adequacy }\end{array}$ & 0.682 \\
\hline $\mathrm{x}^{2}$ value of Bartlett's test of sphericity & 5039.684 \\
\hline Degree of freedom & 171 \\
\hline Significance & 0.000 \\
\hline
\end{tabular}




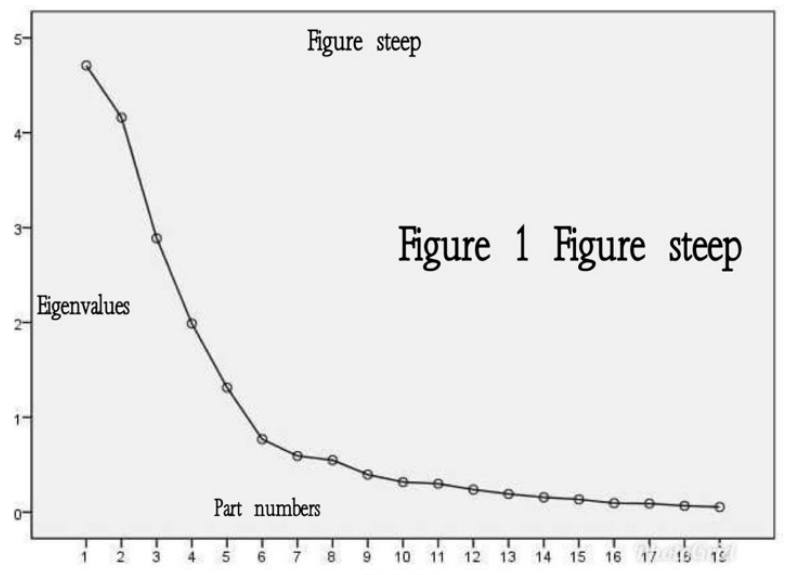

As shown in the Figure 1 Figure steep, the characteristic value of the first factor is very highly. The characteristic values from the $2^{\text {nd }}$ one to the fifth one has declined tremendously, whereas the fifth factor has begun to be slowly and the sixth one has lowered than 1 to be relatively flat and slow, thus it suggests to reserve 3 to 5 factors that will be more adequate.

In the study, there are five factors with the characteristic values greater than 1 in the first time of the factor analysis. This is an exploratory factor analysis with the changes of factorial structure after omission, therefore it needs to work one more time of factor analysis to verify the construct validity of the questionnaire in the $2^{\text {nd }}$ time of factor analysis with 25 items of question after screening (excluding of 10, 15, 18, 20, and 29).

The operational method of the $2^{\text {nd }}$ time factor analysis and the procedure of the $1^{\text {st }}$ time factor analysis are the same with the selected items of 25 questions (excluding of $10,15,18,20$ and 29) $\circ$ The study has 25 questions after omitting the original questionnaire using KMO and Bartlett's test 19 variables whether is suitable to the factor analysis? KMO is Kaiser-Meyer-Olkin's the value of sampling appropriateness. As KMO's less than 0.5, it's not proper for the factor analysis. In the study, the KMO's value is 0.757 to fit for the factor analysis. Furthermore, the $\chi 2$ value of Bartlett's test is 6242.919 (d.f = 300) with the significant level, it represents that the correlated matrix of the population exists for common factors to fit for the factor analysis, see table 2

\begin{tabular}{|l|l|}
\hline \multicolumn{2}{|c|}{$\begin{array}{c}\text { Table 2: KMO and Bartlett's Test Table } \\
\text { (The 2nd Time Factor Analysis) }\end{array}$} \\
\hline $\begin{array}{l}\text { Kaiser-Meyer-Olkin measure of sampling } \\
\text { adequacy }\end{array}$ & 0.757 \\
\hline $\mathrm{x}^{2}$ value of Bartlett's test of sphericity & $6,242.919$ \\
\hline Degree of freedom & 300 \\
\hline Significance & 0.000 \\
\hline
\end{tabular}




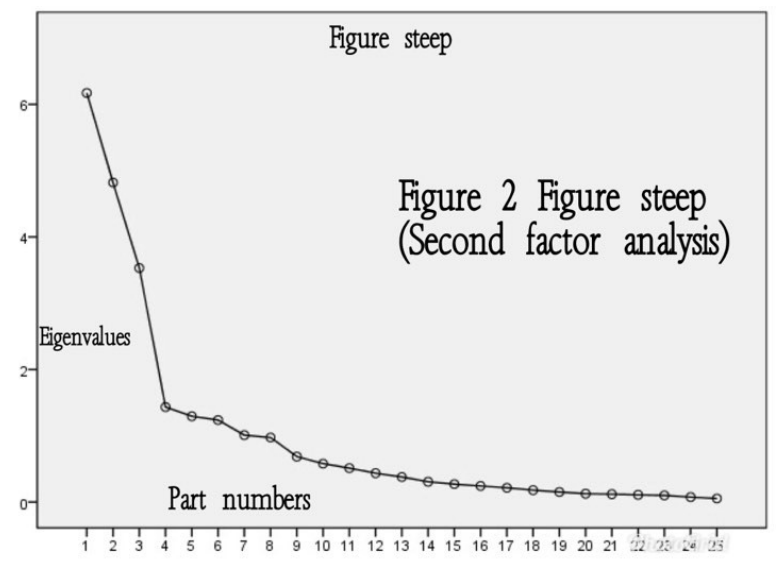

See Figure 2,According to shown in the distribution of steep slope diagram, the slope is flat after the eighth factor, so it is more suitable for selecting four to seven factors. The sixth factor contains items of 1,2 and the seventh factor contains items of 13,14 with less items, there should be the fifth factors left after deletion.

\begin{tabular}{|c|c|c|c|c|c|c|c|c|c|}
\hline \multicolumn{10}{|c|}{$\begin{array}{r}\text { Table 3: The Summary } 1 \text { of Factor Analyses on the e } \\
\text { behavior of electric scooters }\end{array}$} \\
\hline \multirow[t]{2}{*}{ Item } & \multirow{2}{*}{$\begin{array}{c}\text { The contents of } \\
\text { each item }\end{array}$} & \multirow{2}{*}{\begin{tabular}{|c|} 
Explained \\
Variance \\
(Variance \%)
\end{tabular}} & \multirow{2}{*}{$\begin{array}{c}\text { Accumulated } \\
\text { Explained } \\
\text { Variance } \\
\text { (Accumulated } \\
\%)\end{array}$} & \multicolumn{6}{|c|}{ Component (extraction factors) } \\
\hline & & & & $\begin{array}{c}\text { Factor } \\
1\end{array}$ & $\begin{array}{c}\text { Factor } \\
2\end{array}$ & $\begin{array}{c}\text { Factor } \\
3\end{array}$ & $\begin{array}{c}\text { Factor } \\
4\end{array}$ & $\begin{array}{c}\text { Factor } \\
5\end{array}$ & $\begin{array}{l}\text { Common- } \\
\text { ality }\end{array}$ \\
\hline 27 & $\begin{array}{l}\text { I will always pay } \\
\text { attention to the } \\
\text { safety problem when } \\
\text { I am in the } \\
\text { operation. }\end{array}$ & $15.111 \%$ & $15.111 \%$ & 0.864 & 0.175 & 0.309 & & & 0.877 \\
\hline 28 & $\begin{array}{l}\text { I feel very dignified } \\
\text { and comfortable. }\end{array}$ & & & 0.824 & & 0.264 & 0.286 & & 0.840 \\
\hline 8 & $\begin{array}{l}\text { The family worry } \\
\text { that } I \text { 'm going out } \\
\text { alone. }\end{array}$ & & & 0.797 & 0.313 & -0.173 & 0.157 & & 0.796 \\
\hline 9 & $\begin{array}{l}\text { The family is very } \\
\text { busy that they can't } \\
\text { touch frequently. }\end{array}$ & & & 0.760 & 0.147 & -0.150 & 0.385 & & 0.778 \\
\hline 26 & $\begin{array}{l}\text { If's easy to go out to } \\
\text { visit friends. }\end{array}$ & & & 0.523 & 0.412 & 0.107 & -0.354 & -0.454 & 0.828 \\
\hline
\end{tabular}




\begin{tabular}{|c|c|c|c|c|c|c|c|c|c|}
\hline \multirow[t]{2}{*}{ Item } & \multirow{2}{*}{$\begin{array}{l}\text { The contents of } \\
\text { each item }\end{array}$} & \multirow{2}{*}{\begin{tabular}{|c|} 
Explained \\
Variance \\
(Variance \%)
\end{tabular}} & \multirow{2}{*}{\begin{tabular}{|c|} 
Accumulated \\
Explained \\
Variance \\
(Accumulated \\
$\%)$
\end{tabular}} & \multicolumn{6}{|c|}{ Component (extraction factors) } \\
\hline & & & & $\begin{array}{c}\text { Factor } \\
1\end{array}$ & $\begin{array}{c}\text { Factor } \\
2\end{array}$ & $\begin{array}{c}\text { Factor } \\
3\end{array}$ & $\begin{array}{c}\text { Factor } \\
4\end{array}$ & $\begin{array}{c}\text { Factor } \\
5\end{array}$ & $\begin{array}{c}\text { Common } \\
\text { ality }\end{array}$ \\
\hline 6 & $\begin{array}{l}\text { I understand myself, } \\
\text { accept mygelf. }\end{array}$ & $12.901 \%$ & $28.012 \%$ & 0.273 & 0.860 & & & -0.128 & 0.855 \\
\hline 5 & $\begin{array}{l}\text { have flexible hands } \\
\text { and feet to meet } \\
\text { emergency response } \\
\text { and attention. }\end{array}$ & & & 0.137 & 0.743 & 0.203 & 0.178 & & 0.848 \\
\hline 25 & $\begin{array}{l}\text { Due to road design } \\
\text { disorders, people do } \\
\text { not know what to do. }\end{array}$ & & & 0.172 & 0.653 & 0.304 & -0.234 & -0.403 & 0.814 \\
\hline 7 & $\begin{array}{l}\text { My family respects } \\
\text { any of my decisions. }\end{array}$ & & & 0.588 & 0.624 & -0.133 & & & 0.781 \\
\hline
\end{tabular}

Table 5: The Summary 3 of Factor Analyses on the elderly peoples' driving behavior of electric scooters

\begin{tabular}{|c|c|c|c|c|c|c|c|c|c|}
\hline \multirow[t]{2}{*}{ Item } & \multirow{2}{*}{$\begin{array}{l}\text { The contents of } \\
\text { each item }\end{array}$} & \multirow{2}{*}{\begin{tabular}{|l} 
Explained \\
Variance \\
(Variance \%)
\end{tabular}} & \multirow{2}{*}{$\begin{array}{c}\text { Accumulated } \\
\text { Explained } \\
\text { Variance } \\
\text { (Accumulated } \\
\% \text { ) }\end{array}$} & \multicolumn{6}{|c|}{ Component (extraction factors) } \\
\hline & & & & $\begin{array}{c}\text { Factor } \\
1\end{array}$ & $\begin{array}{c}\text { Factor } \\
2\end{array}$ & $\begin{array}{c}\text { Factor } \\
3\end{array}$ & $\begin{array}{c}\text { Factor } \\
4\end{array}$ & $\begin{array}{c}\text { Factor } \\
5\end{array}$ & $\begin{array}{l}\text { Common- } \\
\text { ality }\end{array}$ \\
\hline 22 & $\begin{array}{l}\text { My family wishes to } \\
\text { do everything for me. }\end{array}$ & $12.403 \%$ & $40.414 \%$ & & & 0.820 & -0.102 & & 0.739 \\
\hline 23 & $\begin{array}{l}\text { People care about } \\
\text { economic status. }\end{array}$ & & & & 0.322 & 0.785 & 0.105 & 0.113 & 0.833 \\
\hline 21 & $\begin{array}{l}\text { Reasonable price } \\
\text { within an acceptable } \\
\text { range. }\end{array}$ & & & 0.105 & & 0.728 & & 0.169 & 0.816 \\
\hline 24 & $\begin{array}{l}\text { Riding the scooter } \\
\text { can keep body } \\
\text { balance and safe. }\end{array}$ & & & 0169 & 0.560 & 0.685 & & & 0.834 \\
\hline
\end{tabular}

\begin{tabular}{|c|c|c|c|c|c|c|c|c|c|}
\hline \multirow[t]{2}{*}{ Item } & \multirow{2}{*}{$\begin{array}{l}\text { The contents of } \\
\text { each item }\end{array}$} & \multirow{2}{*}{$\begin{array}{c}\text { Explained } \\
\text { Variance } \\
\text { (Variance \%) }\end{array}$} & \multirow{2}{*}{\begin{tabular}{c|} 
Accumulated \\
Explained \\
Variance \\
(Accumulated \\
$\%)$
\end{tabular}} & \multicolumn{6}{|c|}{ Component (extraction factors) } \\
\hline & & & & $\begin{array}{c}\text { Factor } \\
1\end{array}$ & $\begin{array}{c}\text { Factor } \\
2\end{array}$ & $\begin{array}{c}\text { Factor } \\
3\end{array}$ & $\begin{array}{c}\text { Factor } \\
4\end{array}$ & $\begin{array}{c}\text { Factor } \\
5\end{array}$ & $\begin{array}{l}\text { Common- } \\
\text { ality }\end{array}$ \\
\hline 11 & $\begin{array}{l}\text { The retirement life is } \\
\text { well adapted. }\end{array}$ & $10.977 \%$ & $51.391 \%$ & .283 & & & .796 & & 0.790 \\
\hline 12 & $\begin{array}{l}\text { The user interface is } \\
\text { easy to understand, } \\
\text { easy to operate. }\end{array}$ & & & .125 & .106 & -.102 & .762 & .227 & 0.809 \\
\hline 30 & $\begin{array}{l}\text { I will operate the } \\
\text { electric scooter based } \\
\text { on the current laws } \\
\text { and regulations. }\end{array}$ & & & .430 & & .227 & .701 & & 0.750 \\
\hline
\end{tabular}


Table 7: The Summary 5 of Factor Analyses on the elderly peoples' driving behavior of electric scooters

\begin{tabular}{|c|c|c|c|c|c|c|c|c|c|}
\hline \multirow[t]{2}{*}{ Item } & \multirow{2}{*}{$\begin{array}{l}\text { The contents of } \\
\text { each item }\end{array}$} & \multirow{2}{*}{$\begin{array}{l}\text { Explained } \\
\text { Variance } \\
\text { (Variance \%) }\end{array}$} & \multirow{2}{*}{$\begin{array}{c}\text { Accumulated } \\
\text { Explained } \\
\text { Variance } \\
\text { (Accumulated } \\
\%) \\
\end{array}$} & \multicolumn{6}{|c|}{ Component (extraction factors) } \\
\hline & & & & $\begin{array}{c}\text { Factor } \\
1\end{array}$ & $\begin{array}{c}\text { Factor } \\
2\end{array}$ & $\begin{array}{c}\text { Factor } \\
3\end{array}$ & $\begin{array}{c}\text { Factor } \\
4\end{array}$ & $\begin{array}{c}\text { Factor } \\
5\end{array}$ & $\begin{array}{l}\text { Common- } \\
\text { ality }\end{array}$ \\
\hline 17 & $\begin{array}{l}\text { No walkie-talkie } \\
\text { dedicated lane. }\end{array}$ & $10.721 \%$ & $62.112 \%$ & 0.283 & & & 0.796 & & 0.772 \\
\hline 16 & $\begin{array}{l}\text { Improper planning on } \\
\text { unblocked space } \\
\text { facilities. }\end{array}$ & & & 0.125 & 0.106 & -0.102 & 0.762 & 0.227 & 0.840 \\
\hline 19 & $\begin{array}{l}\text { Headlight and } \\
\text { reflective logo design } \\
\text { ensure traffic safety at } \\
\text { night. }\end{array}$ & & & 0.430 & & 0.227 & 0.701 & & 0.677 \\
\hline & $\begin{array}{l}\text { rce: The study. } \\
\text { are three question } \\
\text { Therefore, it is nal }\end{array}$ & tho & les' dri & as & fo & $\begin{array}{l}\text { on } \\
\text { ies }\end{array}$ & har & & ironmental \\
\hline
\end{tabular}

\section{Conclusions and Suggestions}

\subsection{Conclusions:}

This study aimed at elderly people using electric scooters for behavioral assessment, thus the questionnaires were issued to explore the elderly using the electric mobility of the acceptance and related impact factors to analyze, to enhance the life function of elderly people for the purpose. Secondly, by understanding the assessment and cognition of elderly people using electric scooters, we can provide the future transport authorities with a more appropriate road system. After finishing the questionnaires, valid questionnaires were entered into the computer for log-in and project analysis was conducted using the Social Science Statistics Package Software (SPSS) program. The SPSS22 software was used to carry out factor analysis on the model of the study to understand the various aspects of using the scooters to go out. According to the results of the overall analysis, this study can be summarized five aspects: "the elderly peoples' driving behavior", "the elderly peoples' self-awareness behavior", "the interaction with family", "the elderly peoples' operational behavior", "the elderly peoples' driving environmental activities behavior" are described as follows, see table 3 7:

1. Factor loading more than 0.5 , there are five questions, focusing on physical and mental behavior, so named as "the elderly peoples' driving behavior". Because the family is very busy who won't be able to touch frequently, when using electric scooters, they will always pay attention to safety issues during operation to avoid family concerns and feel dignified and comfortable when using electric scooters.

2. Factor loading more than 0.5 , there are four questions, focusing on self-cognition, so named as "the elderly peoples' self-awareness behavior". For the self-awareness, the family will respect any decision of the operator, although the current road design disorder, the operator knows that self has sufficient emergency response i.e. attention, for the flexible use of electric scooters.

3. Factor loading more than 0.5 , there are four questions, focusing on the family interaction, so named as "the interaction with family". Since the operator can drive safely to keep the body balance moving from top to bottom, the family cares about economy status and hopes to do everything well. Therefore, as long as the electric scooter is reasonable in price, it will purchase the electric scooter within the acceptable range.

4. Factor loading more than 0.5 , there are three questions, focusing on the operational 
behavior, so named as "the elderly peoples' operational behavior". Because the interface of the electric scooter is easy to understand and easy to operate, the operator who is retired with well adapted will operate the electric scooter based on the current laws and regulations.

5. Factor loading more than 0.5 , there are three questions, focusing on driving behavior, therefore named as "the elderly peoples' driving environmental activities behavior". Due to the current space-free environment for motor vehicles without scooters, and the improper planning of unobstructed space facilities, electric scooters have headlamps and reflective signs designed to ensure traffic safety at night.

5.2 Suggestions:

The regulations of current use of electric scooter, it can only be on the sidewalk, is based on the pedestrian traffic management regulations. However, due to large differences in vehicle traffic in counties and cities, it easily leads to the use of electric scooter users and general passers-by in road use with a controversy. Therefore, there are certain risks associated with motorized mobility scooters without dedicated lane. In particular, the traffic quality in Taiwan is unsafe. The design of roads is often confused and the traffic violation rate is very high, while it is quite dangerous for the electric scooter to drive on the road. The government should pay attention to this problem that an appropriate driving space should be planned so that elderly people can use the electric scooter in a safe environment.

Before using electric mobility scooters, it is suggested that government supervision agency should give lectures and teach them some traffic awareness and common sense. They should also regularly return to training to test whether they have the ability to drive electric scooters in order to obtain the best possible safety and security.

The invention of electric scooter is a large blessing for the elderly people, and the electric scooter has the function of saving gasoline money, causing no air pollution, comfortable and safe sitting, speeding within the safe range, and the operation for elderly person easily, it is recommended that the future should continue to evolve with design concepts toward smart operation and digital monitoring.

\section{References}

Chang, Tsz-Yin (2013). Development Trend and Prospect of Medical Equipment Industry at Domestic and Abroad, Global Taiwanese Businessmen E-News, No. 223, $3^{\text {rd }}$ January.

Chiou, Haozheng (2011). Quantitative Research and Statistical Analysis, Taipei: Wunan Books.

Davis, F. D. (1985). A Technology Acceptance Model for Empirically Testing New End-User Information Systems: Theory and Results, Doctoral Dissertation, MIT.

Dion, P. A., Rajshekhar, J., and Dilorenzo-Aiss, J. (1998). An empirical assessment of the Zeithaml, Berry, and Parasuraman service expectations model. The Service Industries Journal, 18(4), 66-86.

Fornell, C. (1992). A national customer satisfaction barometer: The Swedish experience. Journal of Marketing Research, 56(1), 6-21.

Guan Xingsheng, Ruan Lv Yin, Wang Mingtang (2012). Design and Research Methods, Taipei: Chwa Book.

Hsu-Chieh Ching (2000). The Study of Elderly Life Demand: the Example of Tainan City Songbai Recreation Center Songbai Academy. The Master's thesis of National Dr. Sun Yat-sen University Zhongshan Institute of Technology.

Huang Sheau-Ling, Lo Jin-Ling, Yuh Jang, Lin Chia-Chi, Mao Hui-Fen (2003). Use of Assistive Devices in Patients Discharged from Rehabilitation Ward, Taiwan Medicine, 
7(5), 681-8.

Lin Chengzheng, Wang Ling, Huang Xuan Yu (2009). The Study of the Elderly and People with Mobility Problems Using Electric Scooter Safety and Characteristics, in the 2009 Road Traffic Safety and Law Enforcement Workshop.

Ministry of Health and Welfare Medical Device Materials Database, http://mdlicense.itri.org.tw/DB/MDClassification.aspx

National Development Committee, http://www.ndc.gov.tw/Content_List.aspx?n=695E69E28C6AC7F3 Peng, Jiaxin (2000). Gerontology, Taipei : Wunan Book. Sargent, C. A. (2000). Technology for mobility and locomotion. In D. A. Olson \& F. Deruyter (Eds.) Clinician's guide to assistive technology. St. Louis, MO.: Mosby.

Scherer, M. J. (1991). The Matching Person and Technology (MPT) Model (and assessment instruments). Rochester, NY: Author.

The Industrial Bureau, the Ministry of Economic Affairs of the 103 Annual Project Plan for the Implementation of the Final Report (2014).

Win-Chin Lee (2013). Seniors use of Medical electric scooter with the intention Satisfaction Study in Taiwan, The Asian Conference on Psychology \& the Behavioral Sciences 2013 Osaka, Japan - March 28-31.

Win-Chin Lee (2013). The Safety and Behavior of the Machinery Practical Training Factories in Campus. The Asian Conference on the Social Sciences 2013 Osaka, Japan - June 6-9.

Wu, Minglong (2002). SPSS Statistics Application Practice, Taipei: Sung Gang. 